\title{
Innovation Dynamics and Productivity: Evidence for Latin America
}

\section{Gustavo Crespi, Ezequiel Tacsir, and Fernando Vargas}

Although the GDP per capita of most Latin American countries has grown rapidly since 2003, it still significantly lags the levels of industrialized countries. Further, productivity, the main driver of long-term economic growth, has expanded at a lower rate than the world's technological frontier (IDB 2010). Thus, improving productivity is the main challenge for Latin America. But what creates productivity growth? Economies are becoming more knowledge based, and innovation is a key driver of national competitiveness, development, and long-term economic growth. At the firm level, innovation - the transformation of ideas into new products, services, and production processes-leads to a more efficient use of resources, creating sustainable competitive advantages. At the same time, innovation leads to

G. Crespi

Inter-American Development Bank

e-mail: gcrespi@iadb.org

E. Tacsir

CINVE (Montevideo, Uruguay), CIECTI (Buenos Aires, Argentina),

UNU-MERIT (Maastricht, Netherlands)

e-mail: etacsir@gmail.com

F. Vargas

UNU-MERIT

e-mail: fernando.e.vargas.c@gmail.com

(C) Inter-American Development Bank 2016

M. Grazzi and C. Pietrobelli (eds.), Firm Innovation

and Productivity in Latin America and the Caribbean,

DOI 10.1057/978-1-349-58151-1_2 
completely novel sectors, where new firms start operating and new production routines are generated. Change in the production structure is what increases specialization and productivity growth (Katz 2006) as well as the gradual expansion of more knowledge-intensive production activities. Hence, innovation is essential to spur economic growth and to raise living standards. ${ }^{1}$ At the macro-level, research and development (R\&D) spending, innovation, productivity, and per capita income reinforce each other and lead to sustained long-term growth (Hall and Jones 1999; Rouvinen 2002).

Evidence of the relationship between $\mathrm{R} \& \mathrm{D}$, innovation, and productivity has been found in studies of industrialized countries (Griffith et al. 2004; Griffith et al. 2006; OECD 2009; Mairesse and Mohnen 2010). Investing in innovation can have substantial economic payoffs. Firms that invest in innovation are better equipped to introduce technological advances and tend to have higher labor productivity than those that do not. Crespi and Zuñiga (2012) reported that productivity gaps in the manufacturing sector between innovative and non-innovative firms are much higher in Latin America than in industrialized countries. For the typical country in the European Union, the productivity gap is $20 \%$, while for the typical Latin American country it is $70 \%$. Thus, Latin America has great potential to benefit from investment and policies that foster innovation.

One of the most important limitations of previous research on innovation in Latin America was the absence of harmonized and comparable indicators across the different countries, which seriously limited the possibility of inferring policy conclusions that were not affected by country specifics with respect to data quality and coverage. ${ }^{2}$ Also, most of this research focuses on estimating firm-level correlations without attempting to identify market failures or other limitations that harm innovation investment. In this chapter, a wide range of innovation indicators are analyzed in order to describe the innovation behavior of manufacturing firms in Latin America using the World Bank Enterprise Survey (WBES) database. $^{3}$ The authors' objective is to understand the main characteristics of innovative firms in Latin America and to gather new evidence regarding the nature of the innovation process in the region. The next section of this chapter reviews the main findings in the literature on determinants of innovation in both industrialized and developing countries. Using various indicators, the third section presents statistics about the innovation performance of Latin American firms. The ways that innovation relates to firm characteristics in Latin America are explored using a structural model approach to untangle the determinants of innovation investment and performance and productivity at the firm level. The 
fourth section extends the model to gather some evidence regarding the prevalence of spillover effects and the extent to which there is an important heterogeneity regarding returns on innovation.

\section{Literature Background}

Innovation is fundamental to catching up economically and raising living standards. Evidence demonstrates a virtuous circle in which R\&D spending, innovation, productivity, and per capita income mutually reinforce each other and lead to long-term, sustained growth rates (Hall and Jones 1999; Rouvinen 2002; Guloglu and Tekin 2012) and may foster job creation (Vivarelli 2013). ${ }^{4} \mathrm{R} \& \mathrm{D}$ is a source of direct and indirect advantages for firms. There is convincing evidence that shows positive linkages between $\mathrm{R} \& \mathrm{D}$, innovation, and productivity at the firm level in industrialized countries (Griffith et al. 2004; Griffith et al. 2006; OECD 2009; Mairesse and Mohnen 2010; Mohnen and Hall 2013). In addition, R\&D contributes to firms' absorptive capacity, a fundamental prerequisite for learning by doing. Internal R\&D supports better identification of the value of external technology, its assimilation, and its use while expanding the stock of knowledge of firms (Cohen and Levinthal 1989; Griffith et al. 2004). Hence, strengthening in-house technological capabilities induces knowledge spillovers by acquiring machinery and equipment and interacting with other firms.

We note that an important strand of the literature deals with countryor sector-level information. However, considering the innovation results from the investment decisions made by individual firms, the microeconomic analysis has the potential to enlighten the foundations of the correlations found at the macro-level. Taking advantage of innovation surveys, Crépon et al. (1998) were the first to empirically integrate these relationships in a recursive model (Crépon-Duguet-Mairesse [CDM] model), allowing innovation inputs ( $\mathrm{R} \& \mathrm{D}$ investment) to be estimated. Their findings for France corroborated the positive correlation between firm productivity and higher innovation output, even controlling for the skill composition of labor. They also confirmed that a firm's decision to invest in innovation (R\&D) increases with its size, market share, and diversification, and with the demand-pull and technology-push forces.

Building on the CDM model, a new wave of studies that exploited innovation surveys emerged and reported similar results for other industrialized countries. Using different indicators of economic performance, such as labor productivity, multifactor productivity, sales, profit margins, and market value, studies repeatedly showed that technological innova- 
tions (product or process) lead to superior economic performance for the firm (Loof and Heshmati 2002; Loof et al. 2003; Janz et al. 2004; Van Leeuwen and Klomp 2006; Mohnen et al. 2006). This literature also highlights the fact that firm heterogeneity is important to explain innovation activities and their effects on firm performance, and must be controlled for in empirical estimations (Hall and Mairesse 2006; Mairesse and Mohnen 2010; and Chap. 1 of this book). Further, the correlation between product innovation and productivity is often higher for larger firms (Griffith et al. 2006; OECD 2009) and, as expected, in most countries the productivity effect of product innovation is larger in manufacturing than in services (OECD 2009). In addition, a positive association is consistently confirmed between R\&D and innovation outcomes. Firms that invest more intensively in $\mathrm{R} \& \mathrm{D}$ are more likely to develop innovations, once endogeneity is corrected for and controlling is done for firm characteristics such as size, affiliation to group, or type of innovation strategy.

In contrast, evidence with regard to the ability of firms in developing economies to transform R\&D into innovation is not as conclusive. This heterogeneity could be explained by the fact that firms in developing countries are too far from the technological frontier and incentives to invest in innovation are weak or absent (Acemoglu et al. 2006). In this vein, a positive association between $\mathrm{R} \& \mathrm{D}$, innovation, and productivity was found for new industrialized countries such as South Korea (Lee and Kang 2007), Malaysia (Hegde and Shapira 2007), Taiwan (Aw et al. 2008), and China (Jefferson et al. 2006). By investing in R\&D and human capital, these countries managed to narrow their distance from the best practices. However, in many Latin American economies, firms' innovations consist of incremental changes with little or no impact on international markets, and are mostly based on imitation and technology transfer, such as acquisition of machinery and equipment and disembodied technology (Anlló and Suárez 2009; Navarro et al. 2010). In many cases, R\&D is prohibitive financially, and considering the human capital needed, its materialization could require long time horizons (Navarro et al. 2010).

There is evidence that higher levels of investment in innovation (notably in $\mathrm{R} \& \mathrm{D}$ ) lead to a higher propensity to introduce technological innovation in firms in Argentina (Chudnovsky et al. 2006) and Brazil (Correa et al. 2005; Raffo et al. 2008), but research does not support this relationship for Chile (Benavente 2006) or Mexico (Perez et al. 2005). The results regarding the impact of innovation on labor productivity are equally inconclusive for Latin American firms. Raffo et al. (2008) found a significant impact of product innovation for Brazil and Mexico but not for Argentina, though 
Perez et al. (2005), Chudnovsky et al. (2006), and Benavente (2006) failed to find any significant effect of innovation on firm productivity (measured as sales per employee) in Argentinean and Chilean firms. Hall and Mairesse (2006) suggested that the lack of significance of innovation in productivity in developing countries may reflect the very different circumstances surrounding innovation in these economies compared to Western Europe, and they suggested evaluating the effects over longer periods of time (for evidence from Chile, see Benavente and Bravo 2009). ${ }^{5}$

One important pitfall of previous research is related to the lack of homogeneous and comparable data across the different countries in the Latin American region, which may be a factor underlying this heterogeneity. Differences in sampling methodologies, questionnaire design, and data processing for the existing innovation surveys seriously affect the comparability of the results. Crespi and Zuñiga (2012) performed the first comparative study to examine the determinants of technological innovation and its impact on firm labor productivity in manufacturing firms across Latin American countries (Argentina, Chile, Colombia, Costa Rica, Panama, and Uruguay). The authors used micro-data from innovation surveys but the same specification and identification strategy. This exercise showed more consistent results. Specifically, firms that invested in knowledge were more able to introduce technological advances, and those who innovated exhibited superior labor productivity than those who did not. Yet, firm-level determinants of innovation investment are still more heterogeneous than in Organisation for Economic Co-operation and Development (OECD) countries: cooperation, foreign ownership, and exporting increase the propensity to invest in innovation in only half of the countries. At the same time, a firm's linkages and use of different sources of information for innovation activities (scientific and market) have little or no impact on innovation efforts. This illustrates the weak articulation that characterizes national innovation systems in the region. The results regarding productivity, however, highlight the importance of innovation for firms to improve economic performance and to catch up.

Taking these efforts a bit further, the contribution of this chapter is twofold. First, we make use of a homogeneous questionnaire and dataset, which allows us to make more easily generalizable conclusions. Second, most of the previous research on the micro-determinants of innovation and their impacts on productivity deal with structural determinants and, although these results are useful for policy design, they are insufficient in that they are not directly linked to market failures. Our research extends previous analyses by looking at the impacts of spillovers on the determinants of innovation investments. 


\section{Research Questions and Conceptual Framework}

This chapter aims to gather new evidence regarding the determinants of innovation investments-in particular R\&D-in LAC and their impacts on productivity at the firm level. More specifically, we address the following research questions:

1. What are the determinants of innovation investments in LAC?

2. What are the returns on innovation investments?

3 . What are the impacts of innovation outputs on productivity?

4. Is there heterogeneity in the effects of investments in innovation on productivity?

5. Is there any evidence of spillovers that could guide policy design and analysis?

In this chapter, we apply the CDM model to estimate the determinants of innovation (R\&D) and its impact on total factor productivity (TFP). The CDM model has three stages:

1. Firms decide whether or not to invest in R\&D activities and how much to invest.

2. Knowledge (technology) is produced as a result of this investment ("knowledge production" function) (Griliches 1979; Pakes and Griliches 1980).

3. Output is produced using new knowledge (technological innovation) along with other inputs.

Thus knowledge is assumed to have a direct impact on firm economic performance, generally expressed by TFP. In addition to firm characteristics, the model includes external forces acting concurrently on the innovation decisions of firms and indicators of demand-driven innovation (i.e. environmental, health, and safety regulations), technological push (i.e. scientific opportunities), financing (i.e. R\&D subsidies), and spillovers.

The CDM model is intended to deal with the problem of selectivity bias $^{6}$ and endogeneity in the functions of innovation and productivity. The model can be written as follows.

Let $i=1 \ldots N$ index firms 
Equation (2.1) accounts for firms' innovative efforts $I E_{i}^{*}$ :

$$
I E_{i}^{*}=z_{i} \beta+e_{i}
$$

where $I E_{i}^{*}$ is an unobserved latent variable, $z_{i}$ is a vector of determinants of innovation effort, $\beta$ is a vector of parameters of interest, and $e_{i}$ is an error term. We proxy firms' innovative effort $I E_{i}^{*}$ by their $(\log )$ expenditures on R\&D activities per worker denoted by $I E_{i}$ only if firms make (and report) such expenditures. Thus we can only directly estimate equation (2.1) at the risk of selection bias (Griffith et al. 2006). Instead, we assume the following selection equation describing whether the firm decides to do (and/or report) innovation investment or not:

$$
I D_{i}=\left\{\begin{array}{l}
1 \text { if } I D_{i}^{*}=w_{i} \alpha+\varepsilon_{i}>c, \\
0 \text { if } I D_{i}^{*}=w_{i} \alpha+\varepsilon_{i} \leq c
\end{array}\right.
$$

where $I D_{i}$ is a binary endogenous variable for innovation decision that is equal to zero for firms that do not invest in innovation and one for firms investing in innovation activities; $I D_{i}^{*}$ is a corresponding latent variable such that firms decide to do (and/or report) innovation investment if it is above a certain threshold level $c$, and where $w$ is a vector of variables explaining the innovation investment decision, $\alpha$ is a vector of parameters of interest, and $\varepsilon$ is an error term. Conditional on firm $i$ doing innovation activities, we can observe the amount of resources invested in innovation $(I E)$ activities, and write:

$$
I E_{i}=\left\{\begin{array}{c}
I E_{i}^{*}=z_{i} \beta+e_{i} \text { if } I D_{i}=1 \\
0 \text { if } D_{i}=0
\end{array}\right.
$$

Assuming the error terms $e_{i}$ and $\varepsilon_{i}$ are bivariate normal with zero mean, variances $\sigma_{\varepsilon}^{2}=1$ and $\sigma_{e}^{2}$ and correlation coefficient $\rho_{e}$, we estimate the system of equations (2.2) and (2.3) as a generalized Tobit model by maximum likelihood.

The next equation (2.4) in the model is the knowledge or innovation production function:

$$
T I_{i}=I E_{i}^{*} \gamma+x_{i} \delta+u_{i}
$$


where $T I_{i}$ is knowledge outputs by technological innovation (introduction of a new product or process at the firm level), and where the latent innovation effort, $I E_{i}^{*}$, enters as an explanatory variable, $x_{i}$ is a vector of other determinants of knowledge production, $\gamma$ and $\delta$ are vectors of parameters of interest, and $u_{i}$ is an error term. The last equation (2.5) relates innovation to productivity. Firms produce output using a technology represented by a Cobb-Douglas function with labor, capital, raw materials, and knowledge as inputs as follows:

$$
y_{i}=\pi_{1} k_{i}+\pi_{2} m_{i}+\pi_{3} T I_{i}+v_{i}
$$

where output $y_{i}$ is labor productivity ( $\log$ of sales per worker), $k_{i}$ is the log of physical capital per worker (measured by physical investment per worker), $m_{i}$ is the log of raw materials and intermediate goods per worker, and $T I_{i}$ is an explanatory variable that refers to the impact of technological innovation on productivity levels. ${ }^{8}$

In all equations, we control for unobserved industry characteristics by including a full set of two-digit ISIC code dummies. We control for idiosyncratic characteristics of each national innovation system by including a full set of country dummies. We also control for firm size in all equations but the R\&D investment equation (2.2), because R\&D investment intensity is already implicitly scaled for size. As this recursive model does not allow for feedback effects between equations, we implement a threestep estimation routine. First, we estimate the generalized Tobit model (equations 2.2 and 2.3). Second, we estimate the innovation function as a probit equation using the predicted value of $(\log )$ innovation expenditure as the main explanatory variable instead of reported innovation efforts, thus correcting for potential endogeneity in the knowledge production equation. Last, we estimate the productivity equation using the predicted values from the second step to take care of the endogeneity of $T I_{i}$ in equation 2.5 .

As in other studies using innovation survey data, our estimation of the CDM model suffers from several measurement shortcomings. First, both Griliches (1979) and Crépon et al. (1998) used patent data as indicators of technological innovation; however, patent information is almost irrelevant in developing countries where only a very small set of firms innovate at the frontier level. Instead, we use a self-reported innovation output variable, which is qualitative information and much noisier than patent statistics. This type of innovation measurement is very subjective because firms are 
asked to declare whether they innovated or not (introduced a product or a process), and what one firm considers an innovation may not be the same as what other firms consider innovation. Second, the original knowledge production models relate knowledge production to knowledge capital, or the stock of $\mathrm{R} \& \mathrm{D}$ (or innovation investment). As we have cross-sectional information, we can only use the investment in knowledge in the previous year(s), inducing a measurement error in knowledge capital. ${ }^{9}$ These are typical limitations encountered when analyzing R\&D or innovation activities using innovation survey data; many previous studies share these limitations.

Consistent with evidence from developed countries, we also use R\&D as the main dependent variable in equations 2.2 and 2.3. This decision is mostly data driven. According to Crespi and Zuñiga (2012), a better dependent variable could have been total innovation investment, which also includes training and investment in know-how and technology transfer. Unfortunately, the data is not detailed enough to be able to produce information on these additional sources of innovation investment. However, R\&D plays a privileged role as part of the mechanism that leads to creating, adapting, and absorbing new ideas and technological applications (Griffith et al. 2004). Including R\&D as the main dependent variable enables a better identification, assimilation, adaptation, and exploitation of external know-how (Cohen and Levinthal 1989), augmenting the impact of innovation on productivity. From a policy perspective, R\&D consists of an intangible investment and, as such, the most likely to be affected by market failures such as externalities or coordination failures.

In line with previous studies, we not only use technological innovation as a dependent variable but we also estimate separate versions of equation 2.4 for each type of innovation output (product or process). This allows us to explore whether there are different returns for each different class of innovation investment. Lastly, in line with Griffith et al. (2006) and Crespi and Zuñiga (2012), we estimate the CDM model not only for innovative firms but for all firms. Accordingly, we estimate steps (1) and (2) based on reported innovation investment activities. Then, we use the relationship between observable characteristics and innovation spending to predict the likelihood of investing for all firms as a proxy for innovation effort in the knowledge production function. In turn, equation 2.4 (technological innovation) and equation 2.5 (productivity) are estimated for all firms. In equation 2.5 , we include the predicted value of technological innovation. There are two reasons for using this estimation strategy. 
First, the survey does not have a filter and most of the questions are asked to all firms. Second, the model assumes that all firms exert some kind of innovative effort but that not all firms report this activity. The output of these efforts produces knowledge and, thus, enables us to have an estimate of innovation efforts for all firms. ${ }^{10}$ Of course, this strategy is debatable because the approach assumes that innovation efforts and innovation output for firms that do not report innovation activities is the same as for reporting firms. Given that we use estimated independent variables, we need to correct for the standard errors in equations 2.4 and 2.5, which we do by bootstrapping.

\section{DATASET AND EMPIRICAL IMPLEMENTATION}

For this study, we use the WBES, which are firm-level surveys of a representative sample of the private sector of an economy. The World Bank has been conducting these surveys since 2000 for key manufacturing and services sectors in every region of the world. In each country, businesses in the cities or regions of major economic activities are interviewed. The WBES surveys formal (registered) companies with five or more employees, but excludes firms that are wholly government owned. The sampling methodology is stratified random sampling, where firm size, business sector, and geographic region within a country are used as strata. Typically 1200 to 1800 interviews are conducted in larger economies, 360 interviews in medium-sized economies, and 150 interviews in smaller economies.

We use the data from the innovation module of the WBES 2010, which excluded the service sector. As a result, our analysis only covers manufacturing firms for 17 Latin American countries. ${ }^{11}$ In addition to descriptive and performance variables, the surveys include data on a range of innovation activities, such as developing technological products, processes, and non-technological innovation (e.g. managerial, organizational, and marketing practices). A firm is considered an innovator if it has introduced a product or a process innovation in the previous three years (2007-2009). These innovations could be new to the firm or new to the market.

Following Mohnen et al. (2006), we eliminate all firms with sales growth over $250 \%$ and lower than $60 \%$ in the $2007-2009$ period, and firms that reported a ratio of R\&D spending to sales higher than $50 \%$. To maintain consistency with the sample design of the survey, we drop firms that reported less than five employees, and we only consider sectors in countries that have at least five firms surveyed. After we apply this data 
cleaning procedure, we ensure that we have enough observations, setting a threshold of at least $\mathbf{5 0}$ observations in each country (a third of the minimum sample size).

Table 2.1 summarizes the definitions of the main dependent variables and introduces the main control variables. Overall, $70 \%$ of the firms in our dataset are innovators, and product innovators are more pervasive than process innovators ( 57 vs $50 \%$ ). However, successful product innovations are quite limited, on average representing only $14 \%$ of total firm sales. Moreover, only $26 \%$ of firms reported having filed an intellectual property rights (IPR) application, significantly lower than the percentage of firms that innovated. If an IPR application is a signal of novelty, then more than half of the innovators did not protect their innovations or mostly used and adopted already protected technologies. With regards to innovation efforts, the R\&D investment by a typical Latin American firm was about US\$386 per employee. ${ }^{12}$ This small amount of investment would only support hiring a few engineers for a short period of time, which is consistent with adaptive $R \& D$ rather than with highly novel activities.

The main determinants of innovation are divided into four groups: internal capabilities, access to external knowledge, demand pull, and access to financing. The first variable listed under internal capabilities is firm age, which is intended to capture the tacit knowledge accumulated at the firm level through processes such as learning by doing (Arrow 1962). The average firm in the sample is almost 30 years old. The second variable related to capabilities is human capital, which captures the degree of cognitive skills needed to absorb new knowledge and to develop new technologies (Acemoglu et al. 2006). Another indicator of internal capabilities is whether the company is part of an economic group or subsidiary of a multinational corporation. In principle, the economic superiority of multinational firms can be associated with more sophisticated knowledge assets (Girma and Gorg 2007) and easier access to human capital (Kumar and Aggarwal 2005).

Sales diversification is also an indicator of the scope of the productive capabilities of a firm. It provides a sense of the extent to which the firm's knowledge base is specialized in narrowly defined sectors or if it can be used in different sectors. A diversified knowledge base is likely to allow a firm to jump more easily into other sectors, thereby improving the expected returns on its R\&D investments. The final two indicators of internal capabilities are manager experience and previous knowledge stock. We approximate managerial experience using the manager's years 


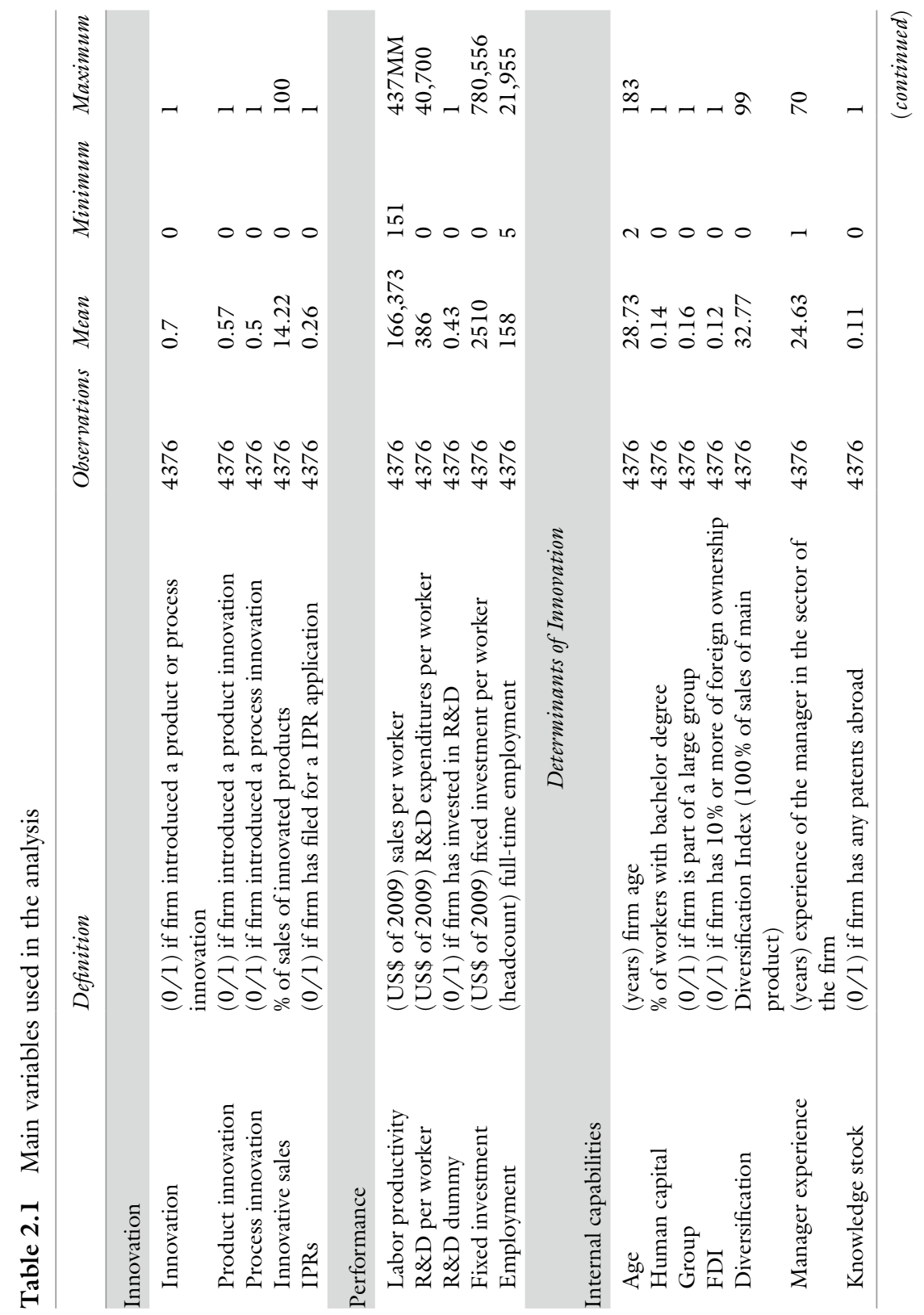


INNOVATION DYNAMICS AND PRODUCTIVITY: EVIDENCE FOR LATIN AMERICA 49

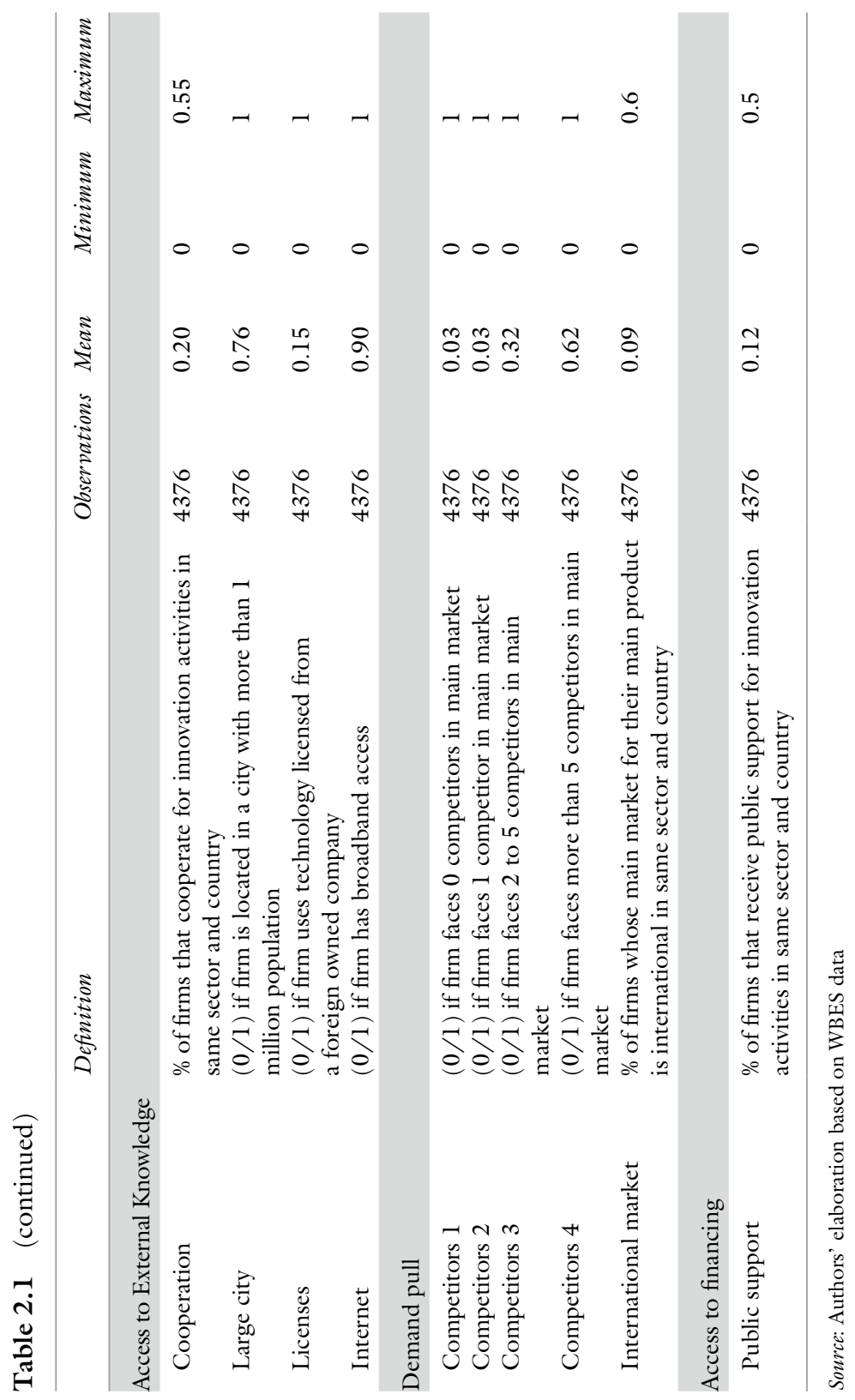


of experience in the same sector. Previous research (Barker and Mueller 2002; Balsmeier and Czarnitzki 2014; Galasso and Simcoe 2011) identified a robust positive relationship between the industry-specific experience of the top manager and the decision to innovate, as well as the share of new product-related sales. These effects were particularly pronounced for small firms in countries with relatively weak institutions. Results suggest that managerial experience affects firm innovations predominately indirectly; for example, by reducing uncertainty about future returns on innovations (Balsmeier and Czarnitzki 2014). With regard to knowledge stock, we include a variable that measures whether the firm has any patents abroad. The patent indicator measures (i) the capacity of the firm to manage intellectual property to protect the results of innovation investments and (ii) the degree of novelty of a firm's innovations, both of which are positively correlated with innovation efforts. Although potentially interesting, unfortunately we do not have enough information to untangle these two effects. We assume that having these patents is exogenous to the decision to invest and the level of investment in innovation. As the process of examination is quite long in patent offices (it usually takes around two years), patents that are granted during the period of inquiry for surveys probably concern inventions that occurred much earlier (for knowledge investment, at least two years before the date surveyed).

Access to external knowledge is normally an important determinant of innovation decisions. We explore this issue by using several variables. First, we use an indicator that measures whether a firm is collaborating with others on innovation activities. In principle, collaboration has ambiguous effects on innovation investment. On the one hand, by allowing firms to share costs and internalize spillovers, collaboration enhances productivity of internal innovation activities, which stimulates further innovation investment (Kamien et al. 1992). On the other hand, collaboration might allow research resources to be pooled, increasing access to effective R\&D (internal plus external), while perhaps saving costs on internal innovation activities (Irwin and Klenow 1996). To deal with the potential endogeneity problem, instead of collaboration activities reported by the firm, we use the average of firms in the same sector and in the same country that collaborated with other organizations pursuing innovation activities.

The second variable measures whether the firm was located in a large city. Previous research has shown the importance of agglomeration economies as key determinants of innovation investments. Agglomeration allows a firm to get access to a pool of specialized resources (mostly human capital) 
and service providers (Moretti 2004). Moreover, knowledge spillovers are normally geographically bounded due to the limits of tacit knowledge (Jaffe et al. 1993). So, in principle, agglomeration economies increase the expected returns on R\&D and innovation-related investments.

Third, acquiring technology through licenses is a potentially important means of accelerating productivity growth, especially in late starter developing countries that are trying to catch up. Yet, the literature has tended to focus on the potential benefits to the seller, overlooking those to the purchaser. Álvarez et al. (2002) found that expenditures on licensing showed exceptionally high rates of return, in the order of twice those of investment in physical capital. This investment significantly improved firms' performance and productivity in Chilean industry during the 1990s. Therefore, we expect that licensing could be a powerful complementary asset to endogenously generated knowledge, in particular for economies that are catching up.

Fourth, the information and communication technologies (ICT) revolution has allowed exponential growth in the volume and circulation of information. Indeed, given that ICTs substantially decrease the costs of information storage and transmission, their diffusion across economies reduces the uncertainty and costs associated with economic interactions. This, in turn, leads to an increase in the volume of transactions, generating higher levels of production for the same set of inputs. In other words, ICTs become a trigger for higher productivity (Chen and Dahlman 2005). Furthermore, ICTs increase organizational capabilities to codify knowledge that otherwise would have remained tacit, accelerating learning processes and productivity growth (Foray 2007), thereby increasing the returns on innovation investment. ${ }^{13}$

Innovation investments are not only the result of internal capabilities or access to external knowledge, they are also the result of incentives. One long-standing issue about innovation concerns the relationship between it and competition. Some researchers argue that innovation is at odds with competition because the need to generate innovation rents to reward innovators typically implies accepting the existence of a market distortion (e.g. by granting IPRs) as the price to pay to gain more innovation. Recent research on this subject has re-evaluated this view, finding that the relationship between these two variables is more complex than previously thought. Aghion et al. (2002) argued that the decision to invest in innovation depends on the degree of competition among firms: the more competitive the sector, the more firms in the sector will be encouraged to innovate 
in order to escape competition. In other words, competition is a key trigger for investment. As a measure of competition faced by the firm, we use a self-reported categorical variable indicating the number of competitors in the main market for the main product. ${ }^{14}$ An additional key component of demand pull is exposure to international markets. Regarding exports, we expect the competition and learning effects from exporting to enhance innovation efforts by firms, notably when local firms have a certain level of technological skills. Braga and Willmore (1991), for Brazilian firms, and Álvarez (2001)), for Chilean firms, reported that exporting firms invested more in innovation (R\&D in these cases). ${ }^{15}$ We use the average exposure of the sector and country, rather than specific firm exposure. ${ }^{16}$

A key variable is the extent to which the firm had access to public support programs for innovation. Public financial support has frequently been found to boost R\&D investment. Most studies conclude that government $\mathrm{R} \& \mathrm{D}$ support leads to additional private $\mathrm{R} \& \mathrm{D}$, innovation expenditures, or innovation outputs, and not to the crowding out of private R\&D by public financial support (Mairesse and Mohnen 2010; Hall and Maffioli 2008). For Latin American firms, public support for R\&D investment is essential (Navarro et al. 2010; Anlló and Suárez 2009). Constraints in securing financing for innovation (high costs of innovation and risks) and the inability of firms to wait for long periods of time (rates of return) are among the most important obstacles to innovation as perceived by firms in Latin America. Although we do not aim to do a full impact evaluation of public funding, we think that it is an important control variable for capturing the costs of financing and as such it should be included in the analysis. ${ }^{17}$ To address the issue of reverse causality related to the costs of financing, we use the proportion of firms that claimed to receive support from government by sector and country as the explanatory variable rather than whether a particular firm had access. We think that this average better captures the generosity of the public support system, which is likely to be more exogenous than the alternative of using a dummy variable for whether the firm has used a particular innovation instrument. It is worth noting that we do not include this variable in the innovation equation, mainly because we think the availability of public support for innovation does not affect the effectiveness of the firm's innovation process. The same argument is valid for excluding the number of competitors and the exposure to international markets of the local industry in this equation. Therefore, while public support and competition may trigger innovation investments, they likely do not affect how these efforts (eventually) become innovations. 
Finally, in all our regressions we control for the size of the firm, as this characteristic has been proven to be a significant determinant of innovation-related activities. The claimed advantages of large-size firms are numerous: a larger spread of R\&D fixed costs over greater output (Cohen and Levinthal 1989), economies of scope relating to R\&D production and diversification, as well as a better appropriation of external knowledge spillovers. ${ }^{18}$ However, here it is important to differentiate between the effects of size on the decision to invest from the impacts of size on investment expenditures. The empirical evidence suggests that there is a positive and proportional relationship between $R \& D$ investment and the size of the firm. That is, large firms invest more in $\mathrm{R} \& \mathrm{D}$, but not proportionally more, once the decision to invest has been taken into account (Cohen and Klepper 1996). Based on this finding, for the generalized Tobit model, we assume the size of the firm affects the decision to invest in innovation but does not affect the intensity of that investment when the decision to invest has been taken into account. For Latin American firms, a positive association between size and the propensity to invest has been systematically reported for many countries (Benavente 2006; Crespi and Peirano 2007; Crespi and Zuñiga 2012). Yet, results regarding the innovation intensity equation, mostly done with R\&D intensity, point out that larger firms are not necessarily the ones who invest the most (for Colombia see Alvarado 2000; for Brazil see De Negri et al. 2007), so we are confident our identification assumption is appropriate. Furthermore, this is the same identification assumption used by many of the empirical implementations of the CDM model reviewed above. In summary, we assume that the decision to invest depends on the size of the firm measured by the (log) employment, but that this variable will not affect the intensity of innovation investments.

\section{The Results}

\section{The Decision to Invest in Innovation and the Intensity of Innovation Expenditure}

Table 2.2 summarizes the findings regarding $\mathrm{R} \& \mathrm{D}$ investment. In general, the decision to invest in $\mathrm{R} \& \mathrm{D}$ is strongly correlated with the size of the firm, with larger firms more likely to invest. The firm's level of knowledge stock, human capital, and diversification also positively influence this decision. Age, however, is negatively correlated with the decision to invest in R\&D, suggesting that new firms are more likely to invest than 
54 G. CRESPI ET AL.

Table 2.2 The determinants of R\&D investment

\begin{tabular}{|c|c|c|}
\hline & RéD per worker & Decision to invest \\
\hline Age & $\begin{array}{l}-0.0034 \\
(0.0017)\end{array}$ & $\begin{array}{l}-0.0049^{\star \star \star} \\
(0.0011)\end{array}$ \\
\hline Human capital & $\begin{array}{l}1.7087^{\star \star \star} \\
(0.2078)\end{array}$ & $\begin{array}{l}0.5291^{\star \star \star} \\
(0.1239)\end{array}$ \\
\hline Group & $\begin{array}{l}0.0595 \\
(0.0945)\end{array}$ & $\begin{array}{l}-0.0145 \\
(0.0585)\end{array}$ \\
\hline FDI & $\begin{array}{l}-0.1336 \\
(0.1134)\end{array}$ & $\begin{array}{l}-0.3300^{\star \star *} \\
(0.0707)\end{array}$ \\
\hline Diversification & $\begin{array}{l}-0.0002 \\
(0.0013)\end{array}$ & $\begin{array}{l}0.0026^{\star \star \star} \\
(0.0008)\end{array}$ \\
\hline Manager experience & $\begin{array}{l}-0.0008 \\
(0.0029)\end{array}$ & $\begin{array}{l}0.0014 \\
(0.0017)\end{array}$ \\
\hline Knowledge stock & $\begin{array}{l}0.3960^{* * *} \\
(0.1077)\end{array}$ & $\begin{array}{l}0.1984^{* \star *} \\
(0.0685)\end{array}$ \\
\hline Cooperation & $\begin{array}{l}-0.1231 \\
(0.4864)\end{array}$ & $\begin{array}{l}0.0187 \\
(0.2955)\end{array}$ \\
\hline Large city & $\begin{array}{l}0.1253 \\
(0.0964)\end{array}$ & $\begin{array}{l}-0.0674 \\
(0.0533)\end{array}$ \\
\hline License & $\begin{array}{l}0.2385^{\star \star *} \\
(0.0914)\end{array}$ & $\begin{array}{l}0.1832^{\star \star \star} \\
(0.0589)\end{array}$ \\
\hline Broadband & $\begin{array}{l}0.4003^{* * *} \\
(0.1561)\end{array}$ & $\begin{array}{l}0.4952^{\star \star \star} \\
(0.0783)\end{array}$ \\
\hline Competitor 2 & $\begin{array}{l}0.3323 \\
(0.3012)\end{array}$ & $\begin{array}{l}0.0251 \\
(0.1685)\end{array}$ \\
\hline Competitors 3 & $\begin{array}{l}-0.0013 \\
(0.2333)\end{array}$ & $\begin{array}{l}0.0226 \\
(0.1246)\end{array}$ \\
\hline Competitors 4 & $\begin{array}{l}-0.1134 \\
(0.2296)\end{array}$ & $\begin{array}{l}-0.0755 \\
(0.1225)\end{array}$ \\
\hline International markets & $\begin{array}{l}-0.1231 \\
(0.4864)\end{array}$ & $\begin{array}{l}-0.0201 \\
(0.3007)\end{array}$ \\
\hline Public support & $\begin{array}{l}1.7068^{\star \star \star} \\
(0.7340)\end{array}$ & $\begin{array}{l}1.4029^{\star \star \star} \\
(0.4257)\end{array}$ \\
\hline Employment & - & $\begin{array}{l}0.2121^{\star \star *} \\
(0.0157)\end{array}$ \\
\hline $\begin{array}{l}\text { N } \\
\text { Ll } \\
\text { chi2 } \\
\text { p } \\
\text { rho } \\
\text { chi2_c }\end{array}$ & $\begin{array}{l}4376 \\
-5797.2963 \\
556.1525 \\
0.0000 \\
0.7530 \\
149.7066\end{array}$ & \\
\hline
\end{tabular}

Source: Authors' elaboration based on WBES data

Notes: Coefficients reported are marginal effects, meaning they predict the likelihood of introducing product or process innovation. Standard errors in parentheses

${ }^{*}$ Coefficient is statistically significant at the $10 \%$ level; ** at the $5 \%$ level; ** at the $1 \%$ level; no asterisk means the coefficient is not different from zero with statistical significance 
old firms. Access to external knowledge seems to be very relevant, as the acquisition of licenses and broadband access are positively related with the decision to invest. In contrast, firms that operate in sectors with higher levels of cooperation for innovation do not show a higher propensity to invest in $\mathrm{R} \& \mathrm{D}$. Neither the intensity of competition faced by the firm nor the degree of exposure to international markets within the sector in which the firm operates are relevant to the decision to invest. However, firms in sectors that have relatively greater public support for innovation are more likely to engage in $\mathrm{R} \& \mathrm{D}$ activities.

With regards to the determinants of the intensity of investment, we again found that the internal capabilities of firms are very relevant, in particular the presence of qualified workers and previous knowledge stock. Access to external knowledge, licensing, and connectivity are also important and positive determinants of R\&D investment. However, this does not seem to be the case for cooperation, suggesting that the incentives for increasing innovation investments and the benefits of saving costs in collaborative innovation activities noted above are also present in Latin American firms. Competition and exposure to international markets remains insignificant. Finally, public support systems for innovation have a positive influence on the intensity of R\&D expenditures.

Being in a large city and being a foreign controlled firm produced some unexpected results. First, the absence of significance for city size suggests that there are no relevant agglomeration economies. Foreign direct investment (FDI) presents a negative and highly statistical relationship with the decision to invest in R\&D. These results, as in Crespi and Zuñiga (2012), confirm that the FDI that the region has managed to attract does not develop technology locally. One plausible interpretation of this result is that, generally speaking, in technologically lagging countries, multinational firms rarely invest in local R\&D units if the market size is not large enough to justify fixed costs for R\&D or if there is not a specific national academic attractiveness (Raffo et al. 2008). ${ }^{19}$ This result could also mean that multinational firms do not invest in innovation in LAC at all, given that their activity is more focused on exploiting comparative advantages in terms of, for instance, access to natural resources, distribution costs, or labor savings; and they also use technological assets from their headquarters (Navarro et al. 2010). If foreign firms conduct technological activities, they frequently focus on adapting and tailoring products to local markets (with low needs for R\&D investment). 


\section{From Innovation Effort to Innovation Outputs}

Next we consider the estimates of the knowledge production functions (equation 2.4) in Table 2.3, where the reported coefficients are marginal effects. We consider five different outputs: innovation (product or process), product innovation, process innovation, innovative sales (defined as the share of sales from new products), and filing for IPRs. The results for innovation suggest that there is a positive and significant correlation between R\&D investment and the likelihood a firm will innovate. Indeed, a $10 \%$ increase in $\mathrm{R} \& \mathrm{D}$ spending translates into a $1.7 \%$ increase in the probability of innovation. According to the results reported in Table 2.3, this is mostly due to the impacts of R\&D spending on product rather than process innovation. Furthermore, R\&D spending increases the likelihood that a firm will apply for IPRs and that it has a positive impact on innovative sales (an increase of $10 \%$ in $\mathrm{R} \& \mathrm{D}$ spending translates into an increase of $1.6 \%$ in innovative sales).

Of the remaining control variables, some internal capabilities are important determinants of innovation outputs beyond their influence through R\&D. Indeed, highly diversified firms are more likely to introduce any type of innovation. In the same vein, a firm's stock of knowledge, although not significantly correlated with product innovation (and only slightly with process innovation), has a strong effect on the likelihood of the firm applying for IPR protection. Although mostly not significant, human capital is negatively correlated with the likelihood of introducing innovations. This effect is mainly driven by the relationship with product innovation, and remarkably noticeable in estimating innovative sales. We do not have a clear explanation for this unexpected relationship, but we speculate that, if the firms with a higher share of skilled workers are competing in more complex markets, there may be a lack of the required innovation capabilities to develop new successful products in these types of markets. Although potentially interesting, the data available do not allow us to probe this hypothesis.

On the one hand, being part of a group correlates positively with the probability of introducing a product innovation. On the other hand, multinationals are less likely to introduce innovations, particularly process innovations, or file for IPRs. This result could be capturing the sector orientation of most of the subsidiaries in the region, which tend to operate in non-innovation driven sectors.

External knowledge is also an important determinant of innovation results. In particular, licensing is an important channel to acquire 
Table 2.3 The determinants of innovation outputs

\begin{tabular}{|c|c|c|c|c|c|}
\hline & Innovation & Product & Process & $\begin{array}{l}\text { Innovative } \\
\text { sales }\end{array}$ & IPRs \\
\hline & (1) & (2) & (3) & (4) & (5) \\
\hline \multirow{2}{*}{$\begin{array}{l}\text { R\&D per } \\
\text { worker }\end{array}$} & $0.1677^{\star \star}$ & $0.1481^{* \star}$ & 0.1029 & $0.1579^{* * *}$ & $0.1305^{* * *}$ \\
\hline & $(0.0655)$ & $(0.0712)$ & $(0.0671)$ & $(0.0441)$ & $(0.0450)$ \\
\hline \multirow[t]{2}{*}{ Age } & -0.0000 & 0.0001 & -0.0003 & -0.0005 & $0.0013^{* \star \star}$ \\
\hline & $(0.0004)$ & $(0.0005)$ & $(0.0005)$ & $(0.0003)$ & $(0.0004)$ \\
\hline \multirow[t]{2}{*}{ Human capital } & -0.1958 & -0.2068 & -0.0758 & $-0.2709^{\star \star \star}$ & -0.1255 \\
\hline & $(0.1223)$ & $(0.1311)$ & $(0.1250)$ & $(0.0857)$ & $(0.0846)$ \\
\hline \multirow[t]{2}{*}{ Group } & 0.0206 & $0.0543^{\star \star}$ & 0.0091 & 0.0192 & -0.0174 \\
\hline & $(0.0219)$ & $(0.0253)$ & $(0.0237)$ & $(0.0157)$ & $(0.0204)$ \\
\hline \multirow[t]{2}{*}{ FDI } & -0.0441 & -0.0141 & $-0.0919^{* \star *}$ & -0.0186 & $-0.0967^{* \star *}$ \\
\hline & $(0.0282)$ & $(0.0312)$ & $(0.0323)$ & $(0.0175)$ & $(0.0210)$ \\
\hline \multirow[t]{2}{*}{ Diversification } & $0.0021^{\star \star \star}$ & $0.0031^{\star \star *}$ & $0.0006^{*}$ & $0.0009^{* * *}$ & $0.0006^{* \star}$ \\
\hline & $(0.0003)$ & $(0.0003)$ & $(0.0004)$ & $(0.0002)$ & $(0.0003)$ \\
\hline \multirow{2}{*}{$\begin{array}{l}\text { Manager } \\
\text { experience }\end{array}$} & -0.0003 & 0.0001 & -0.0000 & 0.0007 & $-0.0010^{*}$ \\
\hline & $(0.0006)$ & $(0.0007)$ & $(0.0007)$ & $(0.0005)$ & $(0.0006)$ \\
\hline \multirow{2}{*}{$\begin{array}{l}\text { Knowledge } \\
\text { stock }\end{array}$} & 0.0471 & 0.0128 & $0.0663^{*}$ & -0.0164 & $0.2395^{* \star *}$ \\
\hline & $(0.0341)$ & $(0.0361)$ & $(0.0386)$ & $(0.0260)$ & $(0.0372)$ \\
\hline \multirow[t]{2}{*}{ Cooperation } & 0.0939 & 0.0750 & 0.1179 & -0.0263 & 0.1420 \\
\hline & $(0.0930)$ & $(0.1098)$ & $(0.1123)$ & $(0.0670)$ & $(0.1042)$ \\
\hline \multirow[t]{2}{*}{ Large city } & -0.0042 & -0.008 & -0.0135 & -0.0142 & -0.0047 \\
\hline & $(0.0205)$ & $(0.0248)$ & $(0.0254)$ & $(0.0148)$ & $(0.0195)$ \\
\hline \multirow[t]{2}{*}{ License } & $0.0613^{\star \star}$ & $0.0667^{\star \star}$ & $0.0496^{*}$ & $0.0318^{*}$ & 0.0258 \\
\hline & $(0.0280)$ & $(0.0282)$ & $(0.0300)$ & $(0.0191)$ & $(0.0239)$ \\
\hline \multirow[t]{2}{*}{ Broadband } & 0.0362 & $0.0964^{\star \star}$ & 0.0351 & $0.0631^{* *}$ & 0.0369 \\
\hline & $(0.0388)$ & $(0.0420)$ & $(0.0370)$ & $(0.0272)$ & $(0.0259)$ \\
\hline \multirow{2}{*}{$\begin{array}{l}\text { Fixed } \\
\text { investment }\end{array}$} & $0.0174^{\star \star \star}$ & $0.0156^{* \star \star}$ & $0.0244^{* * *}$ & $0.0107^{* \star *}$ & $0.0120^{* \star \star}$ \\
\hline & $(0.0022)$ & $(0.0020)$ & $(0.0020)$ & $(0.0016)$ & $(0.0019)$ \\
\hline \multirow[t]{2}{*}{ Employment } & $0.0229^{* \star *}$ & $0.0179^{* \star *}$ & $0.0247^{* * *}$ & -0.0022 & $0.0497^{* * *}$ \\
\hline & $(0.0062)$ & $(0.0068)$ & $(0.0069)$ & $(0.0052)$ & $(0.0058)$ \\
\hline $\mathrm{N}$ & 4376 & 4376 & 4376 & 4376 & 4376 \\
\hline $\mathrm{Ll}$ & -2394.0886 & -2718.2569 & -2818.4319 & -2197.7553 & -2116.7052 \\
\hline chi2 & 695.0068 & 850.4943 & 652.4171 & 526.3368 & 1163.1858 \\
\hline $\mathrm{P}$ & 0.0000 & 0.0000 & 0.0000 & 0.0000 & 0.0000 \\
\hline
\end{tabular}

Source: Authors' elaboration based on WBES data

Notes: Coefficients reported are marginal effects. Bootstrapped standard errors in parentheses

${ }^{*}$ Coefficient is statistically significant at the $10 \%$ level; ** at the $5 \%$ level; ** at the $1 \%$ level; no asterisk means the coefficient is not different from zero with statistical significance 
technological knowledge for product and process innovations, but this effect is not significant for new IPR applications. Broadband, in contrast, is a significant variable for both the product innovation and the innovative sales models. The size of the firm and the level of fixed investments, as expected, are also important factors affecting results for all classes of innovation, particularly for filing for IPRs in the case of size, and process innovation in the case of fixed investments.

\section{From Innovation Outputs to Productivity}

Given that firm capabilities, connectivity, and innovation efforts have some effect on innovation results, the next step is to explore the extent to which these changes translate into higher productivity levels. This is done by estimating equation 2.5, a traditional Cobb-Douglas production function, which we expand by including a measure of quality of labor input (labor and managerial skills) and the predicted innovation results. The findings summarized in Table 2.4 suggest that innovation has a strong impact on labor productivity, even when controlling for intermediate inputs and capital stock per worker, employment, and human capital. The coefficients reported in this table are elasticities or semi-elasticities, since the dependent variable is the log of sales per employee. Consistent with evidence for industrialized countries, our results confirm a positive impact of technological innovation on productivity. The coefficients are large. Innovative firms are $50 \%$ more productive than non-innovative firms (column 1). In column 2, innovation is split among product and process innovation. Productivity impacts on product innovation seem to be higher, and more significant, than on process innovation (36 vs 19\%). These results remain when using innovative sales rather than the product innovation categorical dummy (column 3). Finally, firms that managed to file for an IPR application strongly increased productivity $(35 \%$, column 4$)$.

\section{From Innovation Spillovers to Productivity}

Although in general it is very tricky to assess for the presence of spillovers in the context of cross-sectional data, it is worth a preliminary exploration. Since the seminal works by Nelson (1959) and Arrow (1962), knowledge has been regarded as a non-rival ${ }^{20}$ and non-excludable ${ }^{21}$ good. If knowledge does indeed have these properties, then rivals may be able to free-ride 
Table 2.4 The impacts of innovation on productivity

\begin{tabular}{|c|c|c|c|c|}
\hline & $\operatorname{Ln}(Q / L)$ & $\operatorname{Ln}(Q / L)$ & $\operatorname{Ln}(Q / L)$ & $\operatorname{Ln}(Q / L)$ \\
\hline & (1) & (2) & (3) & (4) \\
\hline Materials & $\begin{array}{l}0.5025^{\star \star \star} \\
(0.0208)\end{array}$ & $\begin{array}{l}0.5028^{\star \star \star} \\
(0.0191)\end{array}$ & $\begin{array}{l}0.5028^{\star \star \star} \\
(0.0190)\end{array}$ & $\begin{array}{l}0.5070^{\star \star \star} \\
(0.0174)\end{array}$ \\
\hline Capital & $\begin{array}{l}0.0919^{\star \star *} \\
(0.0075)\end{array}$ & $\begin{array}{l}0.0914^{\star \star \star} \\
(0.0078)\end{array}$ & $\begin{array}{l}0.0918^{\star \star \star} \\
(0.0089)\end{array}$ & $\begin{array}{l}0.0903^{\star \star \star} \\
(0.0080)\end{array}$ \\
\hline Human capital & $\begin{array}{l}0.4821^{\star \star \star} \\
(0.0557)\end{array}$ & $\begin{array}{l}0.4915^{\star \star \star} \\
(0.0548)\end{array}$ & $\begin{array}{l}0.5170^{\star \star \star} \\
(0.0556)\end{array}$ & $\begin{array}{l}0.4957^{\star \star \star} \\
(0.0637)\end{array}$ \\
\hline Employment & $\begin{array}{l}0.0777^{\star \star \star} \\
(0.0110)\end{array}$ & $\begin{array}{l}0.0783^{\star \star \star} \\
(0.0099)\end{array}$ & $\begin{array}{l}0.0909^{* \star *} \\
(0.0093)\end{array}$ & $\begin{array}{l}0.0766^{\star \star *} \\
(0.0112)\end{array}$ \\
\hline Manager experience & $\begin{array}{l}-0.0003 \\
(0.0007)\end{array}$ & $\begin{array}{l}-0.0005 \\
(0.0006)\end{array}$ & $\begin{array}{l}-0.0007 \\
(0.0006)\end{array}$ & $\begin{array}{l}-0.0004 \\
(0.0007)\end{array}$ \\
\hline Innovation & $\begin{array}{l}0.5543^{* \star *} \\
(0.0879)\end{array}$ & - & - & - \\
\hline Product innovation & - & $\begin{array}{l}0.3635^{\star \star *} \\
(0.1195)\end{array}$ & - & - \\
\hline Process innovation & - & $\begin{array}{l}0.1860 \\
(0.1307)\end{array}$ & $\begin{array}{l}0.0636 \\
(0.1746)\end{array}$ & - \\
\hline Innovative sales & - & - & $\begin{array}{l}0.5225^{\star \star} \\
(0.2113)\end{array}$ & - \\
\hline IPRs & - & - & - & $\begin{array}{l}0.3477^{\star \star \star} \\
(0.0865)\end{array}$ \\
\hline $\mathrm{N}$ & 4376 & 4376 & 4376 & 4376 \\
\hline $\mathrm{Ll}$ & -3596.6234 & -3596.8416 & -3597.4046 & -3607.396 \\
\hline chi2 & 14787.2106 & 9124.5645 & 13287.8438 & 17278.7706 \\
\hline $\mathrm{P}$ & 0.0000 & 0.0000 & 0.0000 & 0.0000 \\
\hline
\end{tabular}

Source: Authors' elaboration based on WBES data

Notes: Coefficients reported are marginal effects. Bootstrapped standard errors in parentheses

${ }^{*}$ Coefficient is statistically significant at the $10 \%$ level; ** at the $5 \%$ level; ** at the $1 \%$ level; no asterisk means the coefficient is not different from zero with statistical significance

on a firm's investments. Spillovers may create a wedge between private and social returns and a disincentive to private investment in knowledge production. However, spillovers are not automatic and should not be taken for granted in every circumstance because not all knowledge enjoys the properties of a public good with the same intensity. Certainly, the public good rationale of knowledge applies more strongly to generic or scientific knowledge than to technological knowledge, which is more applicable and specific to a firm. ${ }^{22}$ Furthermore, for the public good rationale to be valid, there should be some possibility of free-riding. If the originator 
can protect the results of the knowledge generated (e.g. through barriers to entry or strategic mechanisms), then the potential for market failure declines. Conversely, knowledge generated through collaboration might be more difficult to protect and therefore more prone to spillovers than knowledge generated by individual entities. So, in principle, not all types of innovation lead to the same degree of spillover and thus the intensity of focus for innovation policy varies.

To explore this issue, we assume that a firm will benefit from spillovers if its productivity increases as a result of the innovations introduced by other firms. In this context, we compute innovation by other firms as the average of the innovation propensities at sector and country levels (i.e. we assume that spillovers are mostly the result of within-sector and within-country knowledge flows). In sum, we expand the standard CobbDouglas production function to include these sector-level indicators of innovation intensity. The results are summarized in Table 2.5. In general, within the limitations of the dataset, it is possible to say that there are spillovers of technological innovation, and that these are more related to product than process innovation. Indeed, column 2 shows that the coefficient of sector product innovation is positive and strongly significant, while it is negative and far from significant for sector process innovation. The findings stay the same when IPRs are used as a proxy for innovation (column 4). However, when sector innovative sales are used as a measure of product innovation, the positive correlation remains but is not significant (column 3).

\section{Not All Are the Same: Exploring the Heterogeneous Impacts of Innovation}

To some extent the previous results refer to the typical or representative LAC firm, which is somehow at odds with the tremendous heterogeneity that exists in the region in terms of productivity (IDB 2010). One way to assess whether these impacts are heterogeneous is by simulating the productivity distribution in two scenarios: with and without innovation. This exercise, which is summarized in Fig. 2.1, infers two results. First, the shift to the right of the whole distribution of productivity with innovation is consistent with a positive average impact. Second, the spread of the distribution is larger with innovation, suggesting that the productivity impacts of innovation are not uniform across firms but instead vary according to where the firm is within the productivity distribution. 
Table 2.5 The impacts of innovation on productivity: the search for spillovers

\begin{tabular}{|c|c|c|c|c|}
\hline & $\operatorname{Ln}(Q / L)$ & $\operatorname{Ln}(Q / L)$ & $\operatorname{Ln}(Q / L)$ & $\operatorname{Ln}(Q / L)$ \\
\hline & (1) & (2) & (3) & (4) \\
\hline Material & $\begin{array}{l}0.5020^{* \star *} \\
(0.0172)\end{array}$ & $\begin{array}{l}0.5021^{\star \star \star} \\
(0.0188)\end{array}$ & $\begin{array}{l}0.5026^{* * *} \\
(0.0178)\end{array}$ & $\begin{array}{l}0.5067^{\star \star \star} \\
(0.0181)\end{array}$ \\
\hline Capital & $\begin{array}{l}0.0922^{\star \star \star} \\
(0.0069)\end{array}$ & $\begin{array}{l}0.0916^{\star \star \star} \\
(0.0076)\end{array}$ & $\begin{array}{l}0.0920^{\star \star \star *} \\
(0.0084)\end{array}$ & $\begin{array}{l}0.0902^{\star \star \star} \\
(0.0079)\end{array}$ \\
\hline Human capital & $\begin{array}{l}0.4874^{* * *} \\
(0.0557)\end{array}$ & $\begin{array}{l}0.4927^{\star \star \star} \\
(0.0549)\end{array}$ & $\begin{array}{l}0.5205^{* * *} \\
(0.0588)\end{array}$ & $\begin{array}{l}0.4977^{\star * *} \\
(0.0559)\end{array}$ \\
\hline Employment & $\begin{array}{l}0.0781^{* * *} \\
(0.0087)\end{array}$ & $\begin{array}{l}0.0785^{\star \star \star} \\
(0.0107)\end{array}$ & $\begin{array}{l}0.0912^{\star \star *} \\
(0.0101)\end{array}$ & $\begin{array}{l}0.0767^{\star \star \star} \\
(0.0114)\end{array}$ \\
\hline Manager experience & $\begin{array}{l}-0.0003 \\
(0.0007)\end{array}$ & $\begin{array}{l}-0.0005 \\
(0.0007)\end{array}$ & $\begin{array}{l}-0.0007 \\
(0.0007)\end{array}$ & $\begin{array}{l}-0.0004 \\
(0.0007)\end{array}$ \\
\hline Innovation & $\begin{array}{l}0.4999^{* \star *} \\
(0.0875)\end{array}$ & - & - & - \\
\hline Innovation spillovers & $\begin{array}{l}0.9817^{\star \star \star} \\
(0.2762)\end{array}$ & - & - & - \\
\hline Product innovation & - & $\begin{array}{l}0.3242^{\star \star *} \\
(0.1188)\end{array}$ & - & - \\
\hline Product spillovers & - & $\begin{array}{l}1.1456^{\star \star \star} \\
(0.4180)\end{array}$ & - & - \\
\hline Process innovation & - & $\begin{array}{l}0.1854 \\
(0.1403)\end{array}$ & $\begin{array}{l}0.0389 \\
(0.2014)\end{array}$ & - \\
\hline Process spillovers & - & $\begin{array}{l}-0.2052 \\
(0.3846)\end{array}$ & $\begin{array}{l}0.445 \\
(0.3224)\end{array}$ & - \\
\hline Innovative sales & - & - & $\begin{array}{l}0.5099^{* * *} \\
(0.2310)\end{array}$ & - \\
\hline Spillovers sales & - & - & $\begin{array}{l}0.1687 \\
(0.5415)\end{array}$ & - \\
\hline IPRs & - & - & - & $\begin{array}{l}0.3269^{\star \star *} \\
(0.0716)\end{array}$ \\
\hline Spillover IPRs & - & - & - & $\begin{array}{l}0.5050^{\star *} \\
(0.2406)\end{array}$ \\
\hline $\mathrm{N}$ & 4376 & 4376 & 4376 & 4376 \\
\hline $\mathrm{Ll}$ & -3589.6525 & -3590.1052 & -3595.0157 & -3605.3952 \\
\hline chi2 & 10070.4587 & 17809.6335 & 11512.1608 & 9047.2573 \\
\hline $\mathrm{P}$ & 0.0000 & 0.0000 & 0.0000 & 0.0000 \\
\hline
\end{tabular}

Source: Authors' elaboration based on WBES data

Notes: Coefficients reported are marginal effects. Bootstrapped standard errors in parentheses

${ }^{*}$ Coefficient is statistically significant at the $10 \%$ level; ** at the $5 \%$ level; *** at the $1 \%$ level; no asterisk means the coefficient is not different from zero with statistical significance 


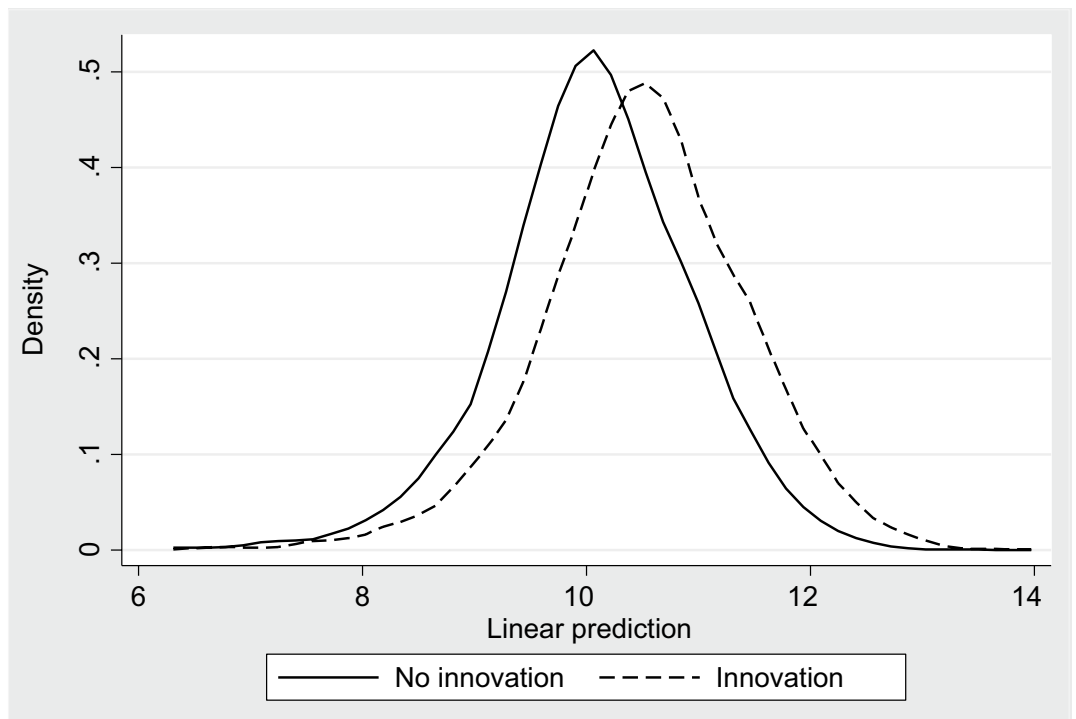

Fig. 2.1 The heterogeneous productivity impacts of innovation (Source: Authors)

To explore this issue further, we use a regression quartile approach to estimate the impacts of innovation on productivity according to the productivity levels of the firms. The results of this exercise are presented in Table 2.6. In general, the returns on innovation depend on the position of the firm within the productivity distribution. For companies at the bottom of the distribution, private returns are not higher than $35 \%$; however, returns increase to more than $65 \%$ for companies at the top of the distribution. It is also worth noting that private returns on innovation are not that different between the first three quartiles of the productivity distribution (between 30 and $40 \%$ ). The big leap is observed between this group and the top $10 \%$ of firms. Interestingly the gap between the bottom and the top of the distribution is also observed in the human capital premium. In fact, while this premium is $17 \%$ for firms at the bottom end of the distribution, it grows to almost the $77 \%$ for firms at the top.

Although these results require further exploration, they could have important consequences for policy design. For example, if low productivity is due to firms that cannot innovate because of financial constraints, returns at the bottom of the distribution would be higher than returns at 
Table 2.6 The heterogeneous impacts of innovation

\begin{tabular}{|c|c|c|c|c|c|}
\hline & Q10 & $Q 25$ & $Q 50$ & $Q 75$ & $Q 90$ \\
\hline & (1) & (2) & (3) & (4) & (5) \\
\hline Innovation & $\begin{array}{l}0.3328 * * * \\
(0.0657)\end{array}$ & $\begin{array}{l}0.2980^{* * *} \\
(0.0658)\end{array}$ & $\begin{array}{l}0.3005^{* * *} \\
(0.0609)\end{array}$ & $\begin{array}{l}0.3845 * * * \\
(0.1178)\end{array}$ & $\begin{array}{l}0.6559^{* * *} \\
(0.1600)\end{array}$ \\
\hline Materials & $\begin{array}{l}0.7445^{* * *} \\
(0.0122)\end{array}$ & $\begin{array}{l}0.7010^{* * *} \\
(0.0108)\end{array}$ & $\begin{array}{l}0.6429 * * * \\
(0.0092)\end{array}$ & $\begin{array}{l}0.5415^{* * *} \\
(0.0140)\end{array}$ & $\begin{array}{l}0.4229^{* * *} \\
(0.0204)\end{array}$ \\
\hline Capital & $\begin{array}{l}0.0562 * * * \\
(0.0058)\end{array}$ & $\begin{array}{l}0.0631 \text { *** } \\
(0.0052)\end{array}$ & $\begin{array}{l}0.0667 * * * \\
(0.0056)\end{array}$ & $\begin{array}{l}0.0804^{* * *} \\
(0.0074)\end{array}$ & $\begin{array}{l}0.1020^{* * *} \\
(0.0105)\end{array}$ \\
\hline Human capital & $\begin{array}{l}0.1708^{* * *} \\
(0.0427)\end{array}$ & $\begin{array}{l}0.2500^{* * *} \\
(0.0323)\end{array}$ & $\begin{array}{l}0.3970 * * * \\
(0.0479)\end{array}$ & $\begin{array}{l}0.6177 * * * \\
(0.0794)\end{array}$ & $\begin{array}{l}0.7661^{* * *} \\
(0.1043)\end{array}$ \\
\hline Employment & $\begin{array}{l}0.0305^{* * *} \\
(0.0065)\end{array}$ & $\begin{array}{l}0.0400 * * * \\
(0.0050)\end{array}$ & $\begin{array}{l}0.0436^{* * *} \\
(0.0067)\end{array}$ & $\begin{array}{l}0.0535^{* * *} \\
(0.0085)\end{array}$ & $\begin{array}{l}0.0768^{* * *} \\
(0.0185)\end{array}$ \\
\hline $\begin{array}{l}\text { Manager } \\
\text { experience }\end{array}$ & $\begin{array}{l}0.0003 \\
(0.0006)\end{array}$ & $\begin{array}{l}0.0004 \\
(0.0004)\end{array}$ & $\begin{array}{l}-0.0001 \\
(0.0005)\end{array}$ & $\begin{array}{l}-0.0011 \\
(0.0008)\end{array}$ & $\begin{array}{l}-0.0027^{*} \\
(0.0014)\end{array}$ \\
\hline$N$ & 4376 & 4376 & 4376 & 4376 & 4376 \\
\hline
\end{tabular}

Source: Authors' elaboration based on WBES data

Notes: Coefficients reported are marginal effects. Bootstrapped standard errors in parentheses

${ }^{*}$ Coefficient is statistically significant at the $10 \%$ level; ** at the $5 \%$ level; ** at the $1 \%$ level; no asterisk means the coefficient is not different from zero with statistical significance

the top. However, the opposite is found to be true (i.e. firms at the bottom of the distribution face lower private returns on innovation than firms at the top), which suggests that there are constraints that affect the resources of the firm related either to the lack of complementary assets (which leads to low private and social returns) or the lack of appropriability (which leads to low private but not necessarily low social returns). Untangling these two situations is important because, if it is the lack opportunities, it does not seem reasonable to focus innovation policy on low productivity firms. If, on the other hand, it is due to appropriability, it is reasonable to focus on low productivity firms. Identifying which constraints dominate is the focus of a future research agenda.

\section{Conclusions}

This chapter has presented an econometric comparison using micro-level data. We investigated drivers of technological innovation and how they feed into productivity at the regional level in Latin America. We estimated 
a common structural model that described the relationships between knowledge investment, innovation outputs, and firm productivity.

We found strong evidence concerning the relationships between innovation input and output, and innovation output and productivity. In line with the literature, firms that invest in knowledge are more able to introduce new technological advances, and those who innovate have superior labor productivity. The consistency in these two results provides solid evidence for Latin American countries. With these results, we hope to fill in some of the gaps in the literature and alleviate the inconclusiveness of previous studies.

Our findings have important repercussions. Firms that invest in knowledge combine internal capacities with innovations. However, internal capacities are not enough, requiring absorption of technology from abroad. We found that the typical multinational firm operating in Latin America is both less prone to invest locally in R\&D and also less likely to innovate. These results contradict previous positive effects found in Argentina, Panama, and Uruguay (Crespi and Zuñiga 2012); however, particular market conditions or policies to attract FDI could be driving those results. Our results reveal that public support for innovation is a key factor in facilitating investments in innovation by Latin American manufacturing firms, different from Crespi and Zuñiga (2012), who did not find a consistent positive impact of governmental support.

We have provided evidence that the private returns on innovation depend on the type of innovation, with larger effects for product than for process innovation. Similarly, we found evidence that spillovers are stronger for product than process innovation, suggesting that the wedge between private and social returns could be higher for product innovation. This finding could guide policy focus on such innovations. Furthermore, we found the returns on innovation to be higher for the most productive firms. This increasing relationship between returns and productivity is not consistent with the interpretation that financial constraints cause more harm to low productivity firms. However, it is consistent with alternative interpretations related to the lack of innovation opportunities in the case of low productivity firms or that low private returns are the result of poor appropriability. In this case there could still be some hope for policy intervention for these types of firms. These weaknesses seem common among firms in the first three quartiles of the productivity distribution. Clearly, this is an important topic for further research. 


\section{Notes}

1. Hall (2011) presents a short discussion about how the productivity of individual firms aggregate with the economy as a whole.

2. The IDB, together with regional agencies such as the Network of Indicators of Science and Technology (known by its Spanish acronym RICYT for Red de Indicadores de Ciencia y Tecnología), has emphasized the need to develop comparable innovation surveys and has developed suggestions for sample design, data collection, and harmonization of questionnaires based on existing manuals. Anlló et al. (2014) summarize these recommendations.

3. The WBES defines innovation rates as the share of firms introducing product or process innovations. In this chapter, the term 'product innovation' refers strictly to firms that introduced a new or significantly improved product that is new to the firm or the establishment's market between 2007 and 2009. 'Process innovation' refers strictly to firms that introduced new or significantly improved processes that are new to the firm or to the industry in the 2007 to 2009 period. Mohnen and Hall (2013) present the notions of different types of innovation and discuss the way they are measured.

4. Crespi and Tacsir (2011) present empirical evidence of the impact of process and product innovation on employment growth and composition in a sample of Latin American countries.

5. Accordingly, if adjustment costs emerging from weaker innovation systems are higher in developing countries, they may be more important to specific dynamic linkages than in Western economies, for which it is more likely that the cross-sectional estimates of the CDM model can reflect long-run relationships.

6. The problem of selectivity is due to the fact that only a handful of firms report positive investment in R\&D at any particular time. Deleting firms with zero activity would bias the sample.

7. Innovation indicators are noisy (in part because they are subjective measures) and need to correct for errors in variable measurement. Hence, nonobservable factors that affect the probability of innovation may lead companies to invest more in innovation activities. Likewise, there are unobservable factors that explain productivity that may also affect the choice of inputs (which implies correlation between the error in the productivity equation and explanatory variables).

8. It is worth mentioning that the relative significance of product and process innovation on TFP is debatable, especially when sales per worker are used as a proxy. To the extent that product innovation may imply superior quality in production systems and more inputs, we may not see any change in productivity levels. In contrast, we would expect process innovation to directly affect the average cost of production and indirectly impact output and profit 
margins. For France, Mairesse et al. (2005) found that process innovation yields higher returns than product innovation, using TFP as a dependent variable. Yet, this is not always the case in other countries (Griffith et al. (2006) for Germany, Spain, and the UK; Roper et al. (2008) for Ireland).

9. For further discussion on using innovation surveys for economic analysis of innovation see Hall and Mairesse (2006) and Mairesse and Mohnen (2010).

10. As explained by Griffith et al. (2006), workers in firms engage in innovation related tasks not officially recorded as innovation activity (below a certain threshold activities are not recorded) to improve efficiency in production systems or to develop new products.

11. We do not include Brazil in the analysis because innovation variables are not available for this group of firms.

12. Only $43 \%$ of the firms reported some investment in R\&D.

13. In this respect, this chapter considers broadband connectivity a factor behind the decision to invest and the likelihood of obtaining innovation outputs from which productivity effects might be derived.

14. There was a significant amount of missing data across countries for this variable. To maintain the number of observations in the sample, we imputed missing values with the median of the competitors reported by the firms with the same main market in the same sector and country.

15. See Chap. 9 in this book, where a causal relationship between trade and higher productivity is found.

16. Before calculating sector-country averages, firms that did not report their main market in the survey were assumed to focus on local/national markets if they reported exports equal to zero.

17. To properly correct for and evaluate the impact of public support, we would need to model its determinants or, as it is usually done, compare the difference in innovation performance between matched pairs of supported and unsupported firms (give each treated firm a counter-factual).

18. Yet it is also argued that small firms have more flexibility and adaptability (and less complex organizational structures), which favor innovation and the development of new projects (Acs and Audretsch 1988).

19. Recent exemptions are China, India, and some South East Asian countries where technology hotspots are emerging and increasingly attracting R\&D investment and new labs from foreign firms.

20. Once produced, new knowledge can be used simultaneously by many different firms because the new blueprints are not normally associated with physical constraints. This characteristic is an extreme form of decreasing marginal costs as the scale of use increases: although the costs of the first use of new knowledge may be large in that it includes the costs of its generation, further use can be done at negligible small incremental costs (Aghion et al. 2009).

21. The non-excludable nature of knowledge refers to the difficulty and cost of trying to retain exclusive possession of it while, at the same time, putting it to use. 
22. Technological knowledge is also more likely to be protected by IPRs, which provide innovating firms the right to temporarily exclude others from using a new idea commercially so the originators can appropriate the rents of their investments in innovation. In exchange for this, the owner must disclose the invention so anyone can improve upon it. However, IPRs can also generate unintended consequences, as they cause a static market distortion in the form of monopoly power and slower technology diffusion for producers that must pay a higher cost to transfer protected technology. In other words, IPRs also create market distortions that might or might not be compensated by the increased incentives to innovate (De Ferranti 2003).

\section{REFERENCES}

Acemoglu, D., P. Aghion, and F. Zilibotti. 2006. Distance to Frontier, Selection, and Economic Growth. Journal of the European Economic Association 41: 37-74.

Acs, Z.J., and D.B. Audretsch. 1988. Innovation in Large Firms: An Empirical Analysis. American Economic Review 78(4): 678-690.

Aghion, P., N. Bloom, R. Blundell, R. Griffith, and P. Howitt. 2002. Competition and Innovation: An Inverted U Relationship. Working Paper No. W9269. Cambridge, MA: National Bureau of Economic Research (NBER).

Aghion, P., P.A. David, and D. Foray. 2009. Science, Technology and Innovation for Economic Growth: Linking Policy Research and Practice in 'STIG Systems.' . Research Policy 38(4): 681-693.

Alvarado, A. 2000. Dinámica de la Estrategia de Innovación: El Caso de Colombia. Coyuntura Económica 30(3): 61-119.

Álvarez, R. 2001. External Sources of Technological Innovation in Chilean Manufacturing Industry. Estudios de Economía 28(1): 53-68.

Álvarez, R., G. Crespi, and J. Ramos. 2002. The Impact of Licenses on a "Late Starter" LDC: Chile in the 1990s. World Development 30(8): 1445-1460.

Anlló, G., G. Crespi, G. Lugones, D. Suárez, E. Tacsir, and F. Vargas. 2014. Manual para la implementación de encuestas de innovación. IDB-BR-143. Washington, DC: IDB.

Anlló, G., and D. Suárez. 2009. Innovación: Algo más que I+D. Evidencias Ibeoramericanas a partir de las encuestas de innovación: Construyendo las estrategias empresarias competitivas. Unpublished. Buenos Aires: CEPAL-REDES.

Arrow, K.J. 1962. The Economic Implications of Learning By Doing. The Review of Economic Studies 29(3): 155-173.

Aw, B.Y., M.J. Roberts, and D. Yi Xu. 2008. R\&D Investment, Exporting, and Productivity Dynamics. Mimeographed document. Cambridge, MA: NBER.

Balsmeier, B., and D. Czarnitzki. 2014. How Important Is Industry-Specific Managerial Experience for Innovative Firm Performance? Discussion Paper 14-011. Mannheim, Germany: Center for European Economic Research (Zentrum für Europäische Wirtschaftsforschung, or ZEW). 
Barker, V.L., and G.C. Mueller. 2002. CEO Characteristics and Firm R\&D Spending. Management Science 48: 782-801.

Benavente, J.M. 2006. The Role of Research and Innovation in Promoting Productivity in Chile. Economics of Innovation and New Technology 154(5): 301-315.

Benavente, J.M., and C. Bravo. 2009. Innovation, R\&D Investment and Productivity in Latin American and Caribbean Firms: The Chilean Case. Unpublished. Washington, DC: Latin American and Caribbean Research Network, IDB.

Braga, H., and L. Willmore. 1991. Technological Imports and Technological Effort. Journal of Industrial Economics 39(4): 421-432.

Chen, D.H., and C.J. Dahlman. 2005. The Knowledge Economy: The KAM Methodology and World Bank Operations. Working Paper 37256. Washington, DC: World Bank Institute.

Chudnovsky, D., A. Lopez, and G. Pupato. 2006. Innovation and Productivity in Developing Countries: A Study of Argentine Manufacturing Firms Behavior 1992-2001. Research Policy 35: 266-288.

Cohen, W.M., and S. Klepper. 1996. Firm Size and the Nature of Innovation within Industries: The Case of Process and Product R\&D. The Review of Economics and Statistics 782: 232-243.

Cohen, W., and D. Levinthal. 1989. Innovation and Learning: The Two Faces of R\&D. The Economic Journal 99(397): 569-596.

Correa, P., I.G. Sanchez, and H. Singh. 2005. Research, Innovation and Productivity: Firm Level Analysis for Brazil. Mimeographed document. Washington, DC: World Bank.

Crépon, B., E. Duguet, and J. Mairesse. 1998. Research, Innovation and Productivity: An Econometric Analysis at the Firm Level. Economics of Innovation and New Technology 7(2): 115-158.

Crespi, G., and F. Peirano. 2007. Measuring Innovation in Latin America: What We Did, Where We Are and What We Want to Do. Paper presented at the Conference on Micro Evidence on Innovation in Developing Countries UNUMERIT. Maastricht.

Crespi, G., and E. Tacsir. 2011. Effects of Innovation on Employment in Latin America. Paper presented at The Atlanta Conference on Science and Innovation Policy. Atlanta.

Crespi, G., and P. Zuñiga. 2012. Innovation and Productivity: Evidence from Six Latin American Countries. World Development 40(2): 273-290.

De Ferranti, D.M. (ed.). 2003. Closing the Gap in Education and Technology. Washington, DC: World Bank Publications.

De Negri, J.A., L. Esteves, and F. Freitas. 2007. Knowledge Production and Firm Growth in Brazil. Working Paper 21. Brazil: Institute for Applied Economic Research (Instituto de Pesquisa Econômica Aplicada [IPEA]). 
Foray, D. 2007. Tacit and Codified Knowledge. In Elgar Companion to NeoSchumpeterian Economics, ed. H. Hanush and A. Pyka. Northampton, MA: Edward Elgar.

Galasso, A., and T. Simcoe. 2011. CEO Overconfidence and Innovation. Management Science 57: 1469-1484.

Girma, S.A., and H.B. Gorg. 2007. Multinationals Productivity Advantage: Scale or Technology? Economic Inquiry 45(2): 350-362.

Griffith, R., E. Huergo, J. Mairesse, and B. Peters. 2006. Innovation and Productivity Across Four European Countries. Oxford Review of Economic Policy 22(4): 483-498.

Griffith, R., S. Redding, and J. Van Reenen. 2004. Mapping the Two Faces of R\&D: Productivity Growth in a Panel of OECD Industries. The Review of Economics and Statistics 864: 883-895.

Griliches, Z. 1979. Issues in Assessing the Contribution of Research and Development to Productivity Growth. Bell Journal of Economics 101: 92-116.

Guloglu, B., and R.B. Tekin. 2012. A Panel Causality Analysis of the Relationship Among Research and Development, Innovation, and Economic Growth in High-Income OECD Countries. Eurasian Economic Review 2(1): 32-47.

Hall, B. 2011. Using Productivity Growth as an Innovation Indicator. Report for the High Level Panel on Measuring Innovation. Brussels: European Commission, DG Research and Innovation.

Hall, B., and A. Maffioli. 2008. Evaluating the Impact of Technology Development Funds in Emerging Economies: Evidence from Latin America. European Journal of Development Research 202: 172-198.

Hall, B., and J. Mairesse. 2006. Empirical Studies of Innovation in the Knowledge Driven Economy: An Introduction, Economics of Innovation and New Technology. Economics of Innovation and New Technology 15(4/5): 289-299.

Hall, R., and C. Jones. 1999. Why Do Some Countries Produce so Much More Output Per Worker Than Others? The Quarterly Journal of Economics 114(1): 83-116.

Hegde, D., and P. Shapira. 2007. Knowledge, Technology Trajectories, and Innovation in a Developing Country Context: Evidence from a Survey of Malaysian Firms. International Journal of Technology Management 40(4): 349-370.

IDB. 2010. The Age of Productivity: Transforming Economies from the Bottom Up. Development in the Americas. Washington, DC: IDB and Palgrave Macmillan.

Irwin, D.A., and P.J. Klenow. 1996. High-Tech R\&D Subsidies Estimating the Effects of Sematech. Journal of International Economics, 40(3-4): 323-344.

Jaffe, A.B., M. Trajtenberg, and R. Henderson. 1993. Geographic Localization of Knowledge Spillovers as Evidenced By Patent Citations. Quarterly Journal of Economics 108: 577-598. 
Janz, N., H. Loof, and B. Peters. 2004. Innovation and Productivity in German and Swedish Manufacturing Firms: Is There a Common Story? Problems and Perspectives in Management 2: 184-204.

Jefferson, G.H., B. Huamao, G. Xiaojing, and Y. Xiaoyun. 2006. R\&D Performance in Chinese Industry. Economics of Innovation and New Technologies 15(4-5): 345-366.

Kamien, M., S. Oren, and Y. Tauman. 1992. Optimal Licensing of Cost-Reducing Innovation. Journal of Mathematical Economics 21: 483-508.

Katz, J. 2006. Structural Change and Domestic Technological Capabilities. CEPAL Review 89: 55-68.

Kumar, N., and A. Aggarwal. 2005. Liberalization, Outward Orientation and In-House R\&D Activity of Multinational and Local Firms: A Quantitative Exploration for Indian Manufacturing. Research Policy 344: 441-460.

Lee, K., and S.M. Kang. 2007. Innovation Types and Productivity Growth: Evidence from Korean Manufacturing Firms. Global Economic Review 36: 343-359.

Loof, H., and A. Heshmati. 2002. Knowledge Capital and Performance Heterogeneity: A Firm-Level Innovation Study. International Journal of Production Economics 761: 61-85.

Loof, H., A. Heshmati, R. Asplund, and S.O. Nas. 2003. Innovation and Performance in Manufacturing Industries: A Comparison of the Nordic Countries. The Icfaian Journal of Management Research 2: 5-35.

Mairesse, J., P. Mohnen, and E. Kremp. 2005. The Importance of R\&D and Innovation for Productivity: A Reexamination in Light of the 2000 French Innovation Survey. Annales d'Économie et de Statistique 79(80): 487-527.

Mairesse, J., and P. Mohnen. 2010. Using Innovation Surveys for Econometric Analysis. Working Paper 15857. Cambridge, MA: NBER.

Mohnen, P., and B. Hall. 2013. Innovation and Productivity: An Update. Eurasian Business Review 3(1): 47-65.

Mohnen, P., J. Mairesse, and M. Dagenais. 2006. Innovativity: A Comparison across Seven European Countries. Economics of Innovation and New Technology 15(4-5): 391-413.

Moretti, E. 2004. Workers' Education, Spillovers and Productivity: Evidence from Plant-Level Production Functions. American Economic Review 94(3): 656-690.

Navarro, J.C., J.J. Llisterri, and P. Zuñiga. 2010. The Importance of Ideas: Innovation and Productivity in Latin America. In The Age of Productivity: Transforming Economies from the Bottom Up, ed. C. Pages. Development in the Americas. Washington, DC: IDB and Palgrave Macmillan.

Nelson, R.R. 1959. The Simple Economics of Basic Scientific Research. Journal of Political Economy 67: 297.

OECD. 2009. Innovation in Firms: A Microeconomic Perspective. Paris: OECD. 
Pakes, A., and Z. Griliches. 1980. Patents and R and D at the Firm Level: A First Look. Working Paper No. 0561. Cambridge, MA: NBER.

Perez, P., G. Dutrenit, and F. Barceinas. 2005. Actividad Innovadora y Desempeno Economico: un analisis econometrico del caso mexicano. In Indicadores de Ciencia y Tecnologia en Iberoamerica. Buenos Aires, Argentina: RICYT.

Raffo, J., S. Lhuillery, and L. Miotti. 2008. Northern and Southern Innovativity: A Comparison Across European and Latin American Countries. The European Journal of Development Research 20(2): 219-239.

Roper, S., J. Du, and J.H. Love. 2008. Modelling the Innovation Value Chain. Research Policy 376(7): 961-977.

Rouvinen, P. 2002. R\&D-Productivity Dynamics: Causality, Lags, and Dry Holes. Journal of Applied Economics 1: 123-156.

Van Leeuwen, G., and L. Klomp. 2006. On the Contribution of Innovation to Multi-Factor Productivity Growth. Economics of Innovation and New Technologies 15(4-5): 367-390.

Vivarelli, M. 2013. Technology, Employment and Skills: An Interpretative Framework. Eurasian Business Review 3(1): 66-89.

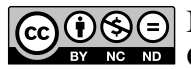

Except where otherwise noted, this work is licensed under a Creative Commons Attribution-NonCommercial-NoDerivatives 3.0 IGO License. To view a copy of this license, visit https://creativecommons.org/licenses / by-nc-nd/3.0/igo/ 